\title{
Tłumaczenie i weryfikacja napisów w filmach i przedstawieniach teatralnych
}

\author{
Pawel Madej \\ Uniwersytet Warszawski \\ p.madej@uw.edu.pl
}

\begin{abstract}
Streszczenie
Badanie napisów jest młoda dyscyplina naukową. Nie ma wielu publikacji analizujacych $i$ prezentujacych kwestię tlumaczenia audiowizualnego, w szczególności napisów filmowych/teatralnych. Dlatego nie ma wielu źródet istotnych informacji dotyczacych problemu.

Przyktady zawarte $w$ tym tekście pochodza $z$ autorskiej obserwacji filmów i spektakli teatralnych. Autor odwotuje się do badań przeprowadzonych wśród kinomanów podzielonych na trzy grupy - osoby z wyksztatceniem filologicznym, osoby z wykształceniem uniwersyteckim oraz osoby bez wyksztatcenia uniwersyteckiego. Tekst dotyczy także napisów z przedstawień teatralnych (Teatr Dramatyczny, Teatr Studio, Nowy Teatr). Wybrano nastepujace spektakle. Kabaret J. Kandera, Rosyjski kontrakt Andrieja Ptatonowa. Ciekawy przypadek psa wieczorową porą Simona Stephensa, Biedny Ja, Suka i Jej nowy koleś Michała Walczaka, Nasza klasa autorstwa Tadeusza Stobodzianka oraz Bent Martina Shermana.

$W$ kolejnych częściach artykutu autor przedstawia realia dotyczace etapów tworzenia napisów filmowych lub przygotowania nadtytułów teatralnych i ich weryfikacji. Odpowiada na pytanie, kto, kiedy i jak ocenia te napisy.
\end{abstract}

Stowa kluczowe: nadtytuły, napisy, grupa docelowa, kod czasu

Abstract

Translation and verification of subtitles in films and theatre performances

Subtitles research is a young discipline in the field of science. There are not many publications analyzing and presenting the issue of audiovisual translation, in particular film/ theatre subtitles. Therefore, there are not many sources of relevant information concerning the issue. Examples included in this text come from the author's observation of films and theatre performances. The author makes reference to the research conducted among moviegoers divided into three groups - people with philological educational background, people with university background, and people without any university education. The text also relates to subtitles from theatre performances (Teatr Dramatyczny, Teatr Studio, Nowy Teatr). The following performances were chosen: Cabaret by J. Kander, The Russian Contract, by Andrei Platonov, The Curious Incident of the Dog in the Night-Time by Simom Stephens, Poor Me, 
the Bitch, and Her New Guy by Michat Walczak, Our Class by Tadeusz Stobodzianek and Bent by Martin Sherman.

In the following sections of the paper, the author presents realia concerning the stages of film subtitles or theatrical supertitles preparation and their verification. He addresses the question who, when and how evaluates these subtitles.

Keywords: supertitles, subtitles, target group, time code

\section{Wstęp}

Tłumaczenie napisów, czy to filmowych, czy też do spektaklu, jest skomplikowanym zajęciem, które wymaga nie tylko wiedzy, kompetencji i umiejętności językowych, ale również orientacji tłumacza w bardzo wielu aspektach życia codziennego. Dotyczy to zarówno tłumaczeń typu voiceover $^{1}$, dubbingu, jak i tworzenia napisów filmowych (subtitles) na potrzeby kina i/lub telewizji, a także teatru, którym to w znacznej mierze niniejszy tekst będzie poświęcony ${ }^{2}$.

Profesjonalnie przygotowane napisy filmowe/teatralne powinny liczyć dwie linie (dopuszczalne są trzy, chociaż rzadko spotykane są sytuacje, gdy tłumacz decyduje się na wykorzystanie trzeciej linii) po maksymalnie czterdzieści znaków każda (wliczając w to spacje i znaki interpunkcyjne). Pojedyncza pełna linia powinna być widoczna na ekranie przez przynajmniej trzy sekundy, aby widz mógł ją przeczytać i właściwie zrozumieć oraz zinterpretować scenę pojawiającą się na ekranie ${ }^{3}$. Jak podaje Grażyna Adamowicz-Grzyb:

Jedna sekunda to minimalny czas wyświetlania krótkiego napisu. Schodzenie poniżej tego limitu sprawia, że tekst jest nieczytelny. Średnio biegły w czytaniu widz potrzebuje na przeczytanie pełnego wersu ok. 3 sekund. Dwie długie linie powinny być z kolei wyświetlane przez 5-6 sekund. (Adamowicz-Grzyb 2013: 45)

Podobne skróty stosowane są przy opracowywaniu wersji lektorskich, aby lektor zdążył przeczytać skrypt w wymaganym przedziale czasowym, a widz zdołał zrozumieć wypowiadane przez niego słowa i rozeznać się w kontekście. Jedyną formą opracowania filmów, w której nie jest wymagane stosowanie skrótów, jest dubbing.

Niniejszy tekst ma zatem za zadanie odpowiedzieć na pytanie, kto, kiedy i w jaki sposób dokonuje ewaluacji (weryfikacji/oceny) napisów filmowych/teatralnych ${ }^{4}$.

\section{Podłoże metodologiczne}

Badania naukowe na temat tłumaczeń audiowizualnych są na gruncie polskim dyscypliną stosunkowo młodą. Na świecie jednak zaczęto zajmować się tą problematyką na szerszą skalę już w pierwszej połowie dwudziestego wieku, jak podaje Grażyna Adamowicz-Grzyb. Wraz z 
rozwojem kina i kinematografii oraz z kolejnymi zdobyczami techniki, przybywało również wszelakich analiz dotyczących języka filmowego, stylu, jak i przeróżnych „mód” na tłumaczenie filmów na inne języki. Owe mody dotarły także na sceny teatralne.

Przykłady przedstawione w niniejszym artykule pochodzą ze zbiorów napisów autora, między innymi z filmów i spektakli przetłumaczonych przez niego. Autor artykułu nawiązuje również do wyników badań przeprowadzonych wśród kinomanów oglądających filmy z napisami.

W kolejnych sekcjach tego artykułu przedstawiam etapy tworzenia napisów filmowych/ teatralnych oraz związane z nimi ograniczenia ${ }^{5}$, aby w końcowym etapie dotrzeć do kwestii weryfikacji tłumaczenia napisów. Autor postara się odpowiedzieć na pytanie, kto i w jakim momencie dokonuje oceny jakości tłumaczenia. Następnie przedstawi i omówi wyniki badań dotyczących ewaluacji napisów filmowych, które zostały przeprowadzone wśród osób uczęszczających do kina „Multikino” w Warszawie w lipcu i w sierpniu 2007 r. (Madej 2009: 114-122 ) oraz obserwacji przedstawień Teatru Dramatycznego, również w Warszawie, we wrześniu i październiku 2017 roku. Wybór spektakli był całkowicie przypadkowy. Analizowano m. in. następujące spektakle: Biedny ja, suka i jej nowy koleś, Kabaret, Bent, Rosyjski kontrakt, Ciekawy przypadek psa nocna pora oraz Nasza klasa.

\section{Proces tworzenia napisów filmowych/teatralnych}

Aby powstały napisy do filmu czy spektaklu, musi zaistnieć szereg sprzyjających okoliczności. Po pierwsze, o zrobienie napisów musi zostać poproszona kompetentna osoba. W polskich realiach sytuacja ta wygląda różnie. Czasem, celem redukcji kosztów, o wykonanie tej czynności proszone są osoby o nieodpowiednich kwalifikacjach, co oczywiście wpływa na jakość tłumaczenia oraz efekt końcowy, czyli odbiór filmu przez widza, postrzeganie filmu/spektaklu przez widownię, krytyków filmowych, etc.

Kolejnym etapem w procesie tworzenia napisów jest konieczność kilkukrotnego obejrzenia filmu/przedstawienia przez tłumacza. Tak zwane 'pierwsze oglądanie' powinno polegać na zwykłym obejrzeniu filmu czy spektaklu i ewentualnym sporządzeniu notatek dotyczących treści. 'Drugie oglądanie' ma dotyczyć identyfikowania ewentualnych problemów językowych. 'Trzecie oglądanie' natomiast, jeżeli w ogóle następuje, ma doprowadzić do uzyskania optymalnego efektu końcowego.

Następnie tłumacz, po otrzymaniu time code'u (czasem time code sheet), zapisuje to, co słyszy, i stara się to przetłumaczyć. Tłumaczenie musi być na tyle zwięzłe, by odpowiadało wymogom technicznym, o których mowa poniżej, i aby widz nie czuł się zmęczony nadmierną 
ilością treści do przeczytania. Jeżeli tłumacz ma do czynienia z tekstem, którego nie rozumie, lub którego nie może usłyszeć/zrozumieć, zastępuje go inna osoba.

Ostatnim i jednocześnie najbardziej pożytecznym etapem pracy jest wspólne oglądanie filmu/przedstawienia przez kilka osób z branży filmowej celem ustalenia prawidłowości synchronizacji napisów z głosem aktorów lub aktora. Spektakle specjalnie na ten cel są często rejestrowane. $\mathrm{Na}$ tym etapie często również mamy do czynienia $\mathrm{z}$ weryfikacją dotychczasowego tłumaczenia.

\section{Ograniczenia w procesie tworzenia napisów filmowych/teatralnych}

Proces tworzenia napisów filmowych podlega szeregowi ograniczeń. Łukasz Bogucki (2004) opisuje je w następujący sposób:

W naszej dyskusji zasada relewancji pełni rolę meta-ograniczenia, które niejako funkcjonuje niezależnie od pozostałych ograniczeń - wymogów technicznych i norm Toury'ego. Tak więc powstały produkt jest wypadkową trzech rodzajów ograniczeń.

To, co pozornie jest przeszkodą natury technicznej (na przykład ograniczenie liczby znaków w wierszu) zmusza thumacza do szukania odpowiednika zarazem spójnego i oszczędnego. Normy tekstowo-językowe rządzące doborem słownictwa pozostają w ścisłym związku z tym zjawiskiem. Niezależnie od przeszkód formalnych i zastosowanych norm i konwencji, zastosowane ekwiwalenty podlegają również meta-ograniczeniu relewancji. Przedrostek ten wymaga komentarza.

\footnotetext{
Wszechstronność pojęcia relewancji oznacza, że warunkuje ona wszelką działalność tłumaczeniową. W przypadku napisów istnieją sytuacje gdzie specyfika procesu nie wpływa na jakość produktu. Należy pamiętać, że dialog filmowy to tekst umiejętnie spreparowany, a jego długość odgrywa również rolę. Zakładając w uproszczeniu, że głównym problemem przy tworzeniu napisów jest konieczność ograniczania ich długości, należy zauważyć, że bariera ta nie dotyczy przynajmniej części dialogu, gdzie oryginał jest na tyle zwięzły, że ograniczenia długości tłumaczenia nie mają znaczenia. Bywają filmy gdzie taka sytuacja jest normą. Tak więc ograniczenia natury technicznej czasami nie mają zastosowania, czasami też, (chociaż rzadko) bywają łamane (Bogucki 2004b).
}

Kanonem modelu według Boguckiego są dwa obszary. Pierwszy z nich stanowią przeszkody techniczne. Drugim zaś są normy tekstowo-językowe dotyczące tłumaczenia zaproponowane przez Toury'ego (Toury 1995: 40). Zasada relewancji występuje tu jako trzecia warstwa, 
jednak może ona, jak twierdzi Bogucki, występować zupełnie niezależnie od pozostałych ograniczeń (Bogucki 2004c).

Według autora, owe ograniczenia mogą być postrzegane na trzech odrębnych poziomach: technicznym, językowym i kulturowym. Zostaną one omówione w zarysie w tejże kolejności.

\subsection{Ograniczenia techniczne}

Poziom pierwszy, czyli najbardziej istotny dla tłumacza, stanowią ograniczenia techniczne. Są one najbardziej oczywiste i z góry ustalone. Tłumaczący musi się im podporządkować. Możemy je podzielić na ograniczenia wyznaczone przez producenta, ograniczenia narzucone przez dystrybutora, oraz ograniczenia dotyczące oczekiwań odbiorców.

Producent rzadko zajmuje się kwestią organizacji napisów do filmu, który wyprodukował, chyba, że ów film ma być pokazywany z jego udziałem na zagranicznych premierach czy festiwalach. Warunki, które stawia producent odnośnie do tworzenia napisów, są więc ukierunkowane na to, jaka grupa docelowa będzie oglądać dany film.

Dystrybucja filmu wiąże się z podobnymi realiami, co produkcja. Tu jednak pojawia się jedna istotna różnica. W przypadku dystrybucji mamy do czynienia z dywersyfikacją, ponieważ często dany film/serial/przedstawienie trafia do kilku społeczności językowych za pośrednictwem jednego dystrybutora. Potrzebne są więc różne wersje językowe. Tak więc i w tym przypadku możemy mówić o ukierunkowaniu na grupę docelową.

I tak, możemy przedstawić relacje producent - dystrybutor - grupa docelowa w następujący sposób:

\section{Producent $\rightarrow$ Dystrybutor}

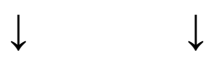

\section{Grupa docelowa}

Schemat 1. Wzajemne relacje między producentem, dystrybutorem a grupą docelową na bazie ograniczeń techniczno-stylistycznych

Jak widać, relacje producenta i dystrybutora sprowadzają się do tzw. target group - grupy docelowej, która ma być odbiorcą filmu. Ona kształtuje to, czego od tłumacza wymagać może producent lub dystrybutor. Ograniczenia techniczne tworzą również grupę wymogów, którym musi podporządkować się producent, dystrybutor i tłumacz. Przyjmuje się, że na ekranie mogą 
pojawić się maksymalnie dwa wersy, pierwszy powinien być krótszy od drugiego, i każda linijka nie powinna zawierać więcej niż 40 znaków. Poza tym, w thumaczeniu zaleca się unikania powtórzeń, wykrzyknień, itp. W przypadku przedstawień teatralnych, tylko wybrane spektakle wystawiane są z napisami.

\subsection{Ograniczenia językowe}

Następny poziom ograniczeń w omawianej kwestii stanowi grupa druga - grupa ograniczeń językowych. Ograniczenia te wypływają z 'wewnętrznej natury' tłumaczącego. Duży wpływ na relacje między tymi ograniczeniami ma, tak jak w przypadku modelu wg Boguckiego, relewancja. Teoria relewancji oparta jest na oddziaływaniu języka tekstów tłumaczonych i języka tłumacza. Dzielimy owe ograniczenia na ograniczenia dotyczące grupy docelowej, ograniczenia kompetencyjne, czy wreszcie ograniczenia dotyczące nieprzekładalności, którym poddaje się tłumacz.

Ograniczenia dotyczące grupy docelowej nadają thumaczowi kierunek pracy. W przypadku dubbingu świetnym przykładem jest tu Bartosz Wierzbięta ${ }^{6}$, tłumacz polskich wersji filmu Shrek. We wspomnianym filmie mamy do czynienia z procesem domestykacji, czyli nadaniem filmowi jak najbardziej lokalnego kolorytu ${ }^{7}$. Pojawiają się tam zwroty typowe TYLKO dla polskiego obszaru językowego, i nie dotyczą one tylko sfery kultury (np. fragmenty tekstów zespołu Lady $\operatorname{Pank}^{8}$ ), ale nawet i polityki.

Ograniczenia kompetencyjne są efektem różnorakiego doświadczenia tłumacza. Dotyczą one tego, czy i w jaki sposób thumacz potrafi poradzić sobie z problemami, na które napotyka w procesie tłumaczenia. Znaną maksymą w świecie tłumaczy audiowizualnych jest to, że thumaczenie jest wtedy dobre, kiedy się go nie zauważa. Uzasadnione więc jest stwierdzenie, że ograniczenia kompetencyjne w jak największym stopniu wpływają na prawidłowe przetłumaczenie filmu czy przedstawienia.

Ograniczenia wynikające $\mathrm{z}$ nieprzekładalności wynikają $\mathrm{W}$ pewnym stopniu $\mathrm{z}$ kompetencji językowych tłumacza; nie oznacza to jednak, że wszystko może być przetłumaczone. Dlatego relacje między ograniczeniami z grupy językowych proponuję przedstawić w następujący sposób:

Ograniczenia kompetencyjne

\section{Ograniczenia dotyczące grupy docelowej}


Schemat 2. Wzajemne relacje między ograniczeniami z grupy ograniczeń językowych

Jak wynika $\mathrm{z}$ analizy, relacje między powyższymi trzema elementami są dosyć płynne; kompetencja tłumacza i zasada relewancji determinują, co i jak zostanie przełożone i czy grupa docelowa będzie usatysfakcjonowana końcowym efektem pracy thumacza.

\subsection{Ograniczenia kulturowe}

Trzeci i zarazem najrzadziej brany pod uwagę poziom ograniczeń w procesie tłumaczenia napisów filmowych czy teatralnych, to poziom ograniczeń kulturowych. Można wyróżnić tu ograniczenia obyczajowe (zwyczajowe), ograniczenia moralnościowe, i wreszcie ograniczenia wypływające z wyznawanej religii (wyznaniowe).

Ograniczenia zwyczajowe dotyczą tego, czy dana społeczność napotyka na inne wzorce społeczne, które różnią się od jej własnych, co w tłumaczeniu jest istotne. Tu nasuwa się przykład zaproponowany przez Gutt'a w jednej z jego publikacji na temat thumaczenia Biblii dla ludów afrykańskich. Gutt podaje, że jedno z plemion, mieszkające w chatach o bardzo stromych dachach, nie było w stanie zrozumieć, jak Jezus i jego pomocnicy weszli przez dach do jednej z chorych. Częstym przykładem tego typu form są tytuły w filmach. Taka sytuacja sytuacja rozdźwięku pomiędzy stanem rzeczy a tym, co i dla kogo się tłumaczy, występuje bardzo często.

Ograniczenia moralnościowe sprowadzają się do tego, czy warto 'igrać' z tym, co moralne w danej społeczności, czy też nie. Tu mam na myśli fillm Fanatic, polskie tłumaczenie Skin. Film ten opowiada o żydowskim chłopcu, który przejawiał zachowania nazistowskie. Na Zachodzie tytuł Fanatic $^{9}$ pozostał w różnych wersjach językowych, w Polsce natomiast, by zaszokować widza, wybrano tytuł Skin.

Ograniczenia wyznaniowe dotyczą bardzo podobnego problemu. Jako przykład można przytoczyć tu film Pasja, The Passion of Christ ${ }^{10}$ autorstwa Mela Gibsona, gdzie tematy dotyczące ludzkiej moralności mieszają się z religijnymi.

W tym przypadku możemy mówić o całkowicie wymiennych relacjach, co przedstawia dokładnie poniższy rysunek:

Schemat 3. Model ograniczeń kulturowych

Ograniczenia zwyczajowe $\rightarrow$ Ograniczenia moralnościowe $\uparrow$

Ograniczenia wyznaniowe 
Wszystkie ograniczenia można pogrupować w ten sposób, aby utworzyły jeden, stosunkowo przejrzysty schemat. Jest on daleki od ideału; mam jednak nadzieję, że zainteresuje on innych badaczy swoją strukturą.

Schemat 4. Model ograniczeń w procesie tworzenia napisów filmowych (za: Madej, 2009)

OGRANICZENIA

TECHNICZNO-STYLISTYCZNE - poziom pierwszy

Dotyczące producenta

Dotyczące dystrybutora

Dotyczące grupy docelowej

JĘZYKOWE - poziom drugi

Dotyczące grupy docelowej

Kompetencyjne

Nieprzekładalności

KULTUROWE - poziom trzeci

Obyczajowe (zwyczajowe)

Moralnościowe

Dotyczące religii (wyznaniowe)

Jak widać, istnieje wiele ograniczeń, które kształtują proces tworzenia napisów filmowych. Opisane zostały one przez Grażynę Adamowicz-Grzyb czy Olgierda Wojtasiewicza . Wiele z nich ma funkcję hamującą, co nie sprzyja najwłaściwszemu tłumaczeniu. Powyższy diagram obrazuje łącznie wszystkie ograniczenia, w kolejności ich istotności dla produkcji (patrząc od dołu). Techniczno-stylistyczne są najbardziej podstawowymi ograniczeniami i dotyczą wszystkich rodzajów produkcji, dlatego też umieszczone zostały na samym dole piramidy. Droga do wypracowania udanej tłumaczeniowo produkcji prowadzi, z ograniczeń technicznostylistycznych, wprost do językowych. Stąd strzałki w górę. Po ograniczeniach językowych następują kulturowe; i też prowadzą do nich strzałki. Owe ograniczenia są w najmniejszym stopniu brane pod uwagę przy produkcjach filmowych czy teatralnych, dlatego też na diagramie stanowią one poziom trzeci, najmniejszy obszarowo na piramidzie, i jednocześnie najrzadziej osiągalny. 


\section{Problem weryfikacji napisów w filmach i przedstawieniach teatralnych}

Praca nad filmem czy przedstawieniem teatralnym to długotrwały proces, w którym wszystko (każdy etap i każdy aspekt) ma znaczenie. Jeżeli film ma być pokazywany społeczności władającej innym językiem, niż język oryginału, każdy nośnik tegoż filmu powinien być wyposażony w napisy. Napisy tworzone są na zamówienie. Weryfikacji napisów powinna dokonać więc osoba zamawiająca usługę. Czasem dzieje się jednak inaczej. O weryfikacji thumaczenia szeroko pisze Barbara Kielar . Dzieli ona proces weryfikacji na trzy etapy:

1. Analiza tekstu.

2. Sprawdzanie przekładu.

3. Ocena przekładu.

Możliwe są różne rozwiązania problemu oceny jakości napisów serialowych, filmowych czy teatralnych. Po pierwsze, weryfikacji może dokonać sam tłumacz. Powinna być to osoba z doświadczeniem i wykształceniem kierunkowym. Ponadto, może ona przekazać tekst do weryfikacji współpracownikom, gdyż częstą rzeczą jest to, że wielkie korporacje filmowe nie zatrudniają poszczególnych tłumaczy danego języka, ale ich zespoły. Inaczej jest z przedstawieniami teatralnymi. Często są to thumacze literatury.

Drugim możliwym rozwiązaniem co do problemu oceny jakości napisów jest zaproszenie na projekcję losowo wybranej grupy osób, która byłaby w stanie wychwycić językowe potknięcia lub niuanse niezauważone przez tłumacza. Osoby te powinny znać język źródłowy na dosyć wysokim poziomie. Dla przykładu należy wspomnieć, że grupowa weryfikacja napisów doprowadziła w roku 2005 do zmiany w polskiej wersji filmu Borat ${ }^{11}$, gdzie, jak podaje Multikino na swojej stronie internetowej, „złagodzono język”.

Trzecim rozwiązaniem jest korekta napisów filmowych po projekcji filmu, w miarę rozprzestrzeniania dystrybucji kopii filmowych. To jednak dotyczy w większości filmów wysokonakładowych. Korekta napisów teatralnych też dokonywana jest na bieżąco.

\section{Opis badań}

Wśród odwiedzających Multikino Warszawa w lipcu i sierpniu 2007 przeprowadzono ankietę dotyczącą weryfikacji napisów filmowych. Autor w każdej z grup zebrał po 50 ankiet.

Wydruk kwestionariusza dostępny jest na końcu pracy.

Badania dotyczyły trzech grup respondentów:

a) osób z wykształceniem filologicznym o kierunku anglistycznym (50 osób),

b) osób z wykształceniem innym niż filologiczne (50 osób), oraz 
c) osób bez wykształcenia wyższego (50 osób).

Ankietowani mieli odpowiedzieć na pięć pytań:

1. Czy podczas projekcji filmu zwracasz uwagę na jakość napisów filmowych? TAK / NIE

2. Czy jakość napisów filmowych może wpłynąć na interpretację treści filmu? TAK / NIE

3. Czy treść napisów filmowych jest dla Ciebie zrozumiała? ZAWSZE / PRAWIE ZAWSZE / NIGDY

4. Czy napisy filmowe są odpowiednią formą tłumaczenia filmów? TAK / NIE

5. Czy uważasz, że konieczne jest dokładne sprawdzenie poprawności językowej napisów? TAK / NIE

Poniższa tabela zestawia wyniki badań:

Tabela 1. Wyniki badań (za: Madej 2009)

\begin{tabular}{|c|l|l|l|}
\hline PYTANIE & \multicolumn{1}{|c|}{ GRUPA Z } \\
WYKSZTALCENIEM & $\begin{array}{r}\text { GRUPA BEZ } \\
\text { WYKSZTALCENIA } \\
\text { FILOLOGICZNYM }\end{array}$ & $\begin{array}{r}\text { GRUPA BEZ } \\
\text { WYKSZTALCENIA } \\
\text { WYŻSZEGO }\end{array}$ \\
\hline 1. & Nie 24\%, Tak 76\%. & Nie 63,4\%, Tak 36,6\%. & Nie 77\%, Tak 23\%. \\
\hline 2. & Tak 93\%, Nie 7\%. & Tak 57\%, Nie 43\%. & Tak 50\%, Nie 50\%. \\
\hline 3. & $\begin{array}{l}\text { Zawsze 56\%, Prawie } \\
\text { Zawsze 44\%, Nigdy 0\%. }\end{array}$ & $\begin{array}{l}\text { Zawsze 66\%, Prawie } \\
\text { Zawsze 34\%, Nigdy 0\%. }\end{array}$ & $\begin{array}{l}\text { Zawsze 75\%, Prawie } \\
\text { Zawsze 23,5\%, Nigdy }\end{array}$ \\
\hline 4. & Tak 98\%, Nie 2\%. & Tak 88\%, Nie 12\%. & Tak 87\%, Nie 13\%. \\
\hline 5. & Tak 98,5\%, Nie 1,5\%. & Tak 53\%, Nie 47\%. & Tak 50\%, Nie 50\%. \\
\hline
\end{tabular}

Jak widać, w odpowiedziach na te same pytania różne grupy ankietowanych odpowiadały w różny sposób. Odpowiedzi tychże osób różnią się w odniesieniu do kwestii konieczności sprawdzania poprawności językowej napisów. Jak wynika z ankiety, według uczestników badania, napisy są odpowiednią formą thumaczenia audiowizualnego. Treść tych napisów jest również dla większości zrozumiała. Napisy i ich treść mogą wpłynąć na zrozumienie filmu według osób wykształconych, natomiast jakość napisów filmowych jest brana pod uwagę przez osoby mające podstawy wykształcenia językowego. To bardzo wiele mówi o świadomości 
odbiorców. Widzowie mający opanowane podstawy języka filmu sami weryfikują jakość napisów. Ostatni badany aspekt jest bardzo istotny z punktu widzenia analizy przedstawionej problematyki. Wyniki badań wskazują, iż widzowie znający język filmu na odpowiednim poziomie mogą/są w stanie sami weryfikować jakość napisów filmowych. Nie inaczej sytuacja wygląda w teatrze.

\section{Napisy w przedstawieniach teatralnych}

Warszawskie teatry od jakiegoś czasu mają w ofercie przedstawienia z napisami angielskimi (tzw. supertitles). We wrześniu i październiku autor przeprowadził obserwację uczestniczącą w kilku teatrach na terenie Warszawy (Teatr Dramatyczny, Teatr Studio, Teatr Nowy). W Teatrze Dramatycznym, jeżeli oryginalny tekst sztuki jest angielski, pracownicy teatru posiłkują się nim przy tworzeniu napisów. Natomiast jeżeli sztuka została napisana w innym języku, tłumacz z języka polskiego przekłada tekst na język angielski. Napisy są dostosowywane do rytmu sztuki, tzn. czasami np. robione są skróty. Napisami „steruje się” ręcznie podczas spektaklu. Wyświetlane są najczęściej nad sceną na wszystkich scenach należących do teatru, w zależności od miejsca, w którym wystawiana jest dana sztuka, czyli: w Pałacu Kultury i Nauki (scena im. G. Holoubka i scena im. H. Mikołajskiej), scena im. T. Łomnickiego na Woli (Kasprzaka 22) oraz scena Przodownik (Olesińska 21).

\section{Wnioski}

Proces tworzenia napisów filmowych/teatralnych jest tematem, który dopiero zaczyna być badany przez językoznawców i kulturoznawców. Niewiele jest również publikacji zgłębiających naturę problemu ograniczeń w tworzeniu napisów. Dlatego też mam świadomość, jako tłumacz i autor, niedoskonałości zaproponowanego przeze mnie modelu. Wymaga on z pewnością rozwinięcia i dogłębnej analizy, zwłaszcza w odniesieniu do teorii relewancji. Nie wyklucza on w żadnym razie pracy Brajerskiej-Mazur. Brajerska-Mazur pisze o ograniczeniach: Zastosowanie technik pragmatycznych przekładu, a w poczet takich technik zaliczyć trzeba techniki tłumaczeniowe, ogranicza straty treściowe thumaczonego tekstu. (Brajerska-Mazur 2003: 37), ani też modelu ograniczeń według Boguckiego, który to model stanowi doskonały punkt odniesienia. Niemniej jednak pozostaje mieć nadzieję, że model przedstawiony w niniejszym artykule będzie stanowił przyczynek do przyszłych badań nad kwestią tłumaczenia napisów. 


\section{Przypisy}

${ }^{1}$ Voiceover - (pol. pogłos/szeptanka), tłumaczenie listy dialogowej danego filmu dla lektora (także znane jako wersja lektorska).

${ }^{2}$ Autor napisał tekst o podobnej tematyce: (Madej 2009: 114-122).

${ }^{3} \mathrm{http}: / /$ kulturabezbarier.org/container/Publikacja/Napisy\%20dla\%20nieslyszacych

20\%20-\%20zasady\%20tworzenia\%20-\%202014.pdf [Data ostatniego dostępu: 12.01.2018].

${ }^{4} \mathrm{~W}$ odniesieniu do napisów filmowych $\mathrm{w}$ tekście pojawiać się będzie słowo jakość. Przez jakość napisów filmowych rozumiem ich poprawność językową, to jest gramatyczną i stylistyczną, ale także podporządkowanie ich normom technicznym i graficznym.

${ }^{5}$ Weryfikacja tworzenia napisów, zdaniem autora, ma miejsce już na poziomie analizy ograniczeń w procesie tworzenia napisów.

${ }^{6}$ https://pl.wikipedia.org/wiki/Bartosz_Wierzbi\%C4\%99ta [Data ostatniego dostępu: 12.01.2018]

${ }^{7}$ domestykacja - (ang. domestication), termin zaproponowany przez Venutiego, dla odróżnienia od foreignization, co oznacza zachowanie kolorytu tekstu (Venuti 1995: 82).

${ }^{8}$ https://lady-pank.com/

${ }^{9}$ https://en.wikipedia.org/wiki/Fanatic_(film) [Data ostatniego dostępu: 12.01.2018].

${ }^{10} \mathrm{https}$ ://en.wikipedia.org/wiki/The_Passion_of_the_Christ [Data ostatniego dostępu: 12.01.2018].

${ }^{11} \mathrm{https} / / /$ pl.wikipedia.org/wiki/Borat [Data ostatniego dostępu: 12-01-2018].

\section{Bibliografia}

Adamowicz-Grzyb, Grażyna (2013) Tłumaczenia filmowe w praktyce. Warszawa: Fortima.

Bogucki, Łukasz (2004a) A Relevance Framework for Constraints on Cinema Subtitling.

Łódź: Wydawnictwo Uniwersytetu Łódzkiego.

Bogucki, Łukasz (2004b) „Relewancja jako ograniczenie w procesie tworzenia napisów”

[pobrane z http://www.jostrans.org/issue01/art_bogucki_pl.php. Data ostatniego dostępu: 12.01.2018].

Bogucki, Łukasz (2004c) "The Constraint of Relevance in Subtitling The Journal of

Specialised Translation" [pobrane z http://www.jostrans.org/issue01/art_bogucki_en.php.

Data ostatniego dostępu: 12.01.2018].

Brajerska-Mazur, Agata (2003) „Trzy poziomy trudności w przekładzie z języka angielskiego na język polski”. [W:] Henryk Duda, Konrad Klimkowski, Richard Sokolowski (red.)

Warsztaty Translatorskie/Workshop on Translation III. Lublin/Ottawa: Towarzystwo

Naukowe Katolickiego Uniwersytetu Lubelskiego and Slavic Research Group University of Ottawa Publishing House; s. 31-51.

Gutt, Ernst-August ([2003] 2004) Dystans kulturowy a przekład. [Modes of Translation and

Cultural Distance. Guest lecture delivered in 2003 at the Jagiellonian University in

Krakow] (tłum.) A. Pokojska. Kraków: Universitas.

https://lady-pank.com/ [Data ostatniego dostępu: 12.01.2018].

Lewicki, Roman (2000) Obcość w odbiorze przekładu. Lublin: UMCS. 
Madej, Paweł Dominik (2009) „Tłumaczenie napisów filmowych i jego weryfikacja”. [W:]

Andrzej Kopczyński, Magdalena Kizeweter (red.) Jakość i ocena ttumaczenia. Warszawa: Academica - Wydawnictwo SWPS.

Tomaszkiewicz, Teresa (2006) Ttumaczenie audiowizualne. Warszawa: Państwowe Wydawnictwa Naukowe.

Toury, Gideon (1995) Descriptive Translation Studies and Beyond. Amsterdam: John Benjamins.

Venuti, Lawrence (1995) The Translator's Invisibility: A History of Translation. London/New York: Routledge.

Wojtasiewicz, Olgierd ([1957] 2000) Wstęp do teorii tlumaczenia. Warszawa: Państwowe Wydawnictwa Naukowe.

https://pl.wikipedia.org/wiki/Bartosz_Wierzbi\%C4\%99ta [Data ostatniego dostępu: 12.01.2018].

https://en.wikipedia.org/wiki/Fanatic_(film) [Data ostatniego dostępu: 12.01.2018]. https://en.wikipedia.org/wiki/The_Passion_of_the_Christ [Data ostatniego dostępu: 12.01.2018].

http://kulturabezbarier.org/container/Publikacja/Napisy\%20dla\%20nieslyszacych 20\%20-\%20zasady\%20tworzenia\%20-\%202014.pdf [Data ostatniego dostępu: 12.01.2018].

https://pl.wikipedia.org/wiki/Borat [Data ostatniego dostępu: 12-01-2018]. 